\title{
Comparative Study on the Procedures, Limits, and Control of Constitutional Revisions
}

\author{
Kodio Ahmed Hedieloum \\ Department of Constitutional Law and Administrative Law, School of Law, Zhongnan University of Economics and Law, \\ Wuhan, China \\ Email: kodiokodio1@163.com
}

How to cite this paper: Hedieloum, K. A. (2019). Comparative Study on the Procedures, Limits, and Control of Constitutional Revisions. Beijing Law Review, 10, 579-615. https://doi.org/10.4236/blr.2019.103034

Received: June 3, 2019

Accepted: June 24, 2019

Published: June 27, 2019

Copyright (c) 2019 by author(s) and Scientific Research Publishing Inc. This work is licensed under the Creative Commons Attribution International License (CC BY 4.0).

http://creativecommons.org/licenses/by/4.0/

\begin{abstract}
People always have the right to reform and change its Constitution. One generation cannot subject future generations to its laws. Constitutional amendments are acts and actions that will make it possible to amend the Constitution. More specifically, these acts and activities will repeal parts of the rules or their entirety and replace them with other laws. These changes are required by the need to breathe the texts and consolidate democracy. Constitutional revision is a mechanism envisaged by any State Constitution to adapt it to the social and political aspirations of the State. It can intervene to correct certain outdated and incomplete provisions in the Constitution. This constitutional mechanism must in principle take into account the spirit of constitutionalism and democracy. It requires that in the process of readjusting the constitution, the separation of powers, human rights and freedoms and the alternation of state power be preserved. This spirit of constitutionalism and democracy means that the Constitution remains above all a sacred instrument, a flagship guide of society to which we must continuously submit or comply. Any constitutional revision must be necessary, relevant and take into account the current political and social environment. A modification of the Constitution is proper if and only if its proposals constitute effective solutions to the problems or weaknesses identified that justified the initiative of the review process. But this mechanism can often become a doorway that can facilitate the destruction of the desacralization of the Basic Law. As main content, through this study, we have highlighted the sound characteristics of constitutional revisions in different countries. The study, through a comparative approach to constitutional provisions, allowed us to highlight the legal specifications of the States that were the subject of our research. Thus, our analyses show that the revision of the Constitution varies from one State to another; from one constitutional system to another. The study also allowed us to analyze the legal framework of constitutional review procedures in constitutionalism. When these rules of form and substance are not respected, it is up to
\end{abstract}


the constitutional court to act as a guarantor of the constitutional order.

\section{Keywords}

Constitution, Constitutional Revision, Constitutionality Review, Democracy, Referendum

\section{Introduction}

In principle, all Constitutions are made to resist the wear and tear of time. However, due to the legal, political, social and other issues contained in the Constitution, it must be possible to adapt it to the changing needs and realities of society. That is why the principle of constitutional revision is enshrined in all modern constitutions. Thus, Rousseau (1896) opines that people are always in control of changing its laws, even the best ones. According to Professor Moderne (2006), revision is formally a procedural technique by which the public authorities expressly and officially amend the text of the Constitution. In material terms, it describes the purpose of the constitutional amendment resulting from this formal procedure. Constitutional revision (sometimes called constitutional amendment) is, therefore, an amendment to a country's political constitution, usually carried out according to the rules established in it. ${ }^{1}$ Constitution changes are presented as necessary corrections to texts that have emerged in use, imperfect, incomplete or unsuited to the political and democratic aspirations of a people at some point in their history.

From the period of the most authoritarian political systems to the current regimes of democracies, the revision of the Constitution has always accompanied the process of building the rule of law and strengthening democracy. Constitutional changes have often been a means of improving the political system of States, whether American, European or African, even if they have sometimes caused local crises of constitutional and political instability. Since the emergence of written constitutions, the doctrine has continuously questioned the mechanisms of constitutional revision as a legal phenomenon in modern states regardless of their system of political governance. In other words, it tries to understand and analyze how to modify an already established Constitution. The challenge of these considerations is a real invitation to blur the boundaries between legal analysis, political philosophy, and ideology (Favoreu et al., 2016). It is important not to confuse these problems.

A legal analysis must therefore strictly distinguish between two phenomena that may appear to be of the same kind, namely: the revision and drafting of a constitution. In both cases, a text is negotiated, drafted and adopted. These texts cover mostly the same legal matters. Moreover, the States that have taken a formal Constitution are anxious to respect requirements whose liberal thought has ${ }^{1}$ Implementation of services in the field of forest management in Szubin Forest District in 2016. [Tender documents : T30282854]. (2015). MENA Report, n/a. 
made a legacy that is now widely shared to the point of being invoked even by those who only seem to comply with them. But this unity of vision covers entirely different situations. A real political upheaval can result in a modest constitutional review. In this case, the adoption of a wholly new Constitution can be an expression of a profound continuity of power relations. But on the other hand, an adopted "new Constitution" may only be a revision of the old Constitution and a "small" amendment to the constitutional text may hide a legal revolution $^{2}$. This labyrinth of terminology, therefore, leads us to make a semantic analysis of the vocabularies used to designate the fact for a people who are trying to give other legal orientations to their constitutional rules at a time of their evolution.

\subsection{Analysis of the Terminologies Used to Refer to the Action of Retouching Constitutional Rules and the Definition of the Notion of the Constitution}

\subsubsection{Analysis of the Terminologies Used to Refer to the Action of Retouching Constitutional Rules}

The Constitutions, therefore, use various terminologies to refer to their revision. Most of the Constitutions refer to the terminology of "revision.." In the United States, the Constitution refers to constitutional "amendments." The French Constitution of 1791 refers to constitutional "reform" in Articles 1 and 3 of Title VII and constitutional "change" in Articles 2 and 4 of Title VII, which are the work of a Review Assembly.

In these conditions, we can ask ourselves whether the terms Reform, Change and Revision have the same meaning. When we refer to article 115 of the French Constitution of 1793, it is possible to see the distinction between "revision" and "change" of the Constitution. Indeed, this article provides that half of the primary assemblies of the departments duly formed may request the revision of the Constitution act or the change of some of these articles. Here we have the feeling that the idea of "revision" refers to "total revision," and that of "change" refers to the "partial revision" of the Constitution. However, Laboulaye (Laboulaye, 1851) will make the inverse association in his analyses and prefers the expressions "total change" and "partial revision." In France, the problem becomes even more complex when the case of the draft Gironde Constitution of 1793 is mentioned

\footnotetext{
${ }^{2}$ For example, it is difficult for a lawyer to distinguish between the drafting and adoption of the 1978 Spanish Constitution, which definitively puts an end to the Franco regime, and the adoption of the 1958 French Constitution, considered as the transition from the Fourth to the Fifth Republic. Also, in some former Soviet bloc countries, where events of democratic transitions sometimes leading to fundamental changes in the political order have been accompanied by an apparently almost imperceptible change in constitutional rules. Thus, Hungary's current Constitution is still the one of August 10,1948, the original version of which barely masked a Stalinist dictatorship. Simple constitutional "revisions" have enabled the country to adopt a democratic Constitution that gives a strong place to the values of the rule of law.

${ }^{3}$ In Africa, mention can be made of the Constitutions of Chad of 31 March 1996 (Article 223), the Democratic Republic of Congo (Article 218), Mali of 25 February 1992 (Article 118) and Senegal of 22 January 2001 (Article 103). In Europe, the French Constitutions of 1958 (Articles 89 and 11), Spain of 29 December 1978 (Article 166), Italy of 1 January 1948 (Article 138) all refer to "revisions"
} 
in an attempt to understand the meaning of the legal vocabularies used in the field of constitutional revision. Indeed, the draft Constitution presented by the Girondins at the national convention of 15 and 161793 used a multitude of ambiguous terms that made the text of Article 1 on the revision of the Constitution obscure. Because the text in question stated in these terms: "A National Convention shall be convened whenever it is necessary to reform the constitutional act, to change or modify any of its parts, or to add any new provision to it." ${ }^{\text {I }}$ In so doing, it was difficult to make a clear distinction between the different terms ("reform," "change," "modify," "add") used by the French constituent's 1793 draft Constitution. If we analyze in the strict sense of the term, we see that the French constituent in his project would like to stress that there were as many meanings as words. Therefore, "Change" would not mean "change" or "reform," and vice versa. But how does all this differ in law? As we delve deeper into the legal literature, we discover other terminology such as the "correction of constitutional articles" used by some 18th-century doctrines. For some authors, strictly speaking, "revising" an article of the Constitution is simply a matter of reviewing it, without necessarily changing it at the end, unlike "reforming" which means correcting an identified defect (Berriat-Saint-Prix, 1853). In other words, the word "reform" implies the existence of a defect to be corrected but also refers to a new examination that may lead to a confirmation of the text of the legal rule in question.

All these doctrinal disputes aim to determine whether there is a connotation in legal constitutionalism of the term "revision," which would imply that by this we mean a priori the total revision, or a priori the partial revision. Or if, on the contrary, the term should be considered neutral, so that neither the expression "totals revision" nor the expression "partial revision" is pleonastic. The authors disagree on this emphasis of the word "revision," and the three readings meet. For Favoreu and Pfersmann (Favoreu \& Pfersmann, 1992), "the simple term "revision" already seems to recall, not a modification within a given set of rules, but a "total" change in the current system." For (Le Pillouer, 2009) on the contrary, "the particular connotation attached to the notion of "revision," when it comes to the constitution," refers to "a "partial," or "relative" modification." Carré de Malberg's argument suggests that he too associates the revision with the partial amendment since he prefers the word "repeal" for the total change. To do this, it makes (partial) revision and (total) repeal two branches of a higher notion of "reformation. Finally, other authors do not associate the term with any meaning, or more precisely, they assume that it is appropriate for all senses. Thus (Vedel, 1949), for whom the revision of a constitution is its amendment, "i.e. the repeal of some (or all) of its rules and their replacement by other rules". It is on this basis of terminological neutrality that the word "revision" will be used in this article to refer to all operations consisting in retouching an already established Constitution.

${ }^{4}$ See Artice 1st of the Gironde Constitution of 1793. 
The constitutional revision itself now covers a multitude of forms that the study of comparative law can make confusing, but for which thorough research seems essential to understand its specificity better. The legal and political practices of the various States on this subject reveal a great diversity of democratic culture. For example, the amendments to the US Constitution of 1787, the revisions to the German Basic Law of 1949 or Austria of 1945 all have their characteristics because of the political history of each of the countries in question. From this legal diversity, it is also appropriate to analyze some theoretical notions relating to the Notion of Constitution that has long opposed doctrines.

\subsubsection{The Notion of a Constitution}

These theoretical considerations make the classic distinction between, on the one hand, formal and material constitutions and, on the other hand, rigid and flexible Constitutions. Classically, the Constitution is defined in both the legal and material sense, which has implications for the revision regime. In the legal sense, the Constitution is "the norm that governs the drafting of laws, the general norms under which the activity of state bodies is carried out. This rule of the creation of essential legal norms of the State and the procedure of legislation form the Constitution in the literal, original and strict sense of the word" (Kelsen, 1928). According to the formal definition, the concept of Constitution is dissociated from politics. In other words, the law is "rid of" all the elements that are external to it (Kelsen, 1962). In its material sense, Kelsen (1962) says of the Constitution that it is the Constitution that is at stake when modern constitutions contain, not only rules on the organs and procedure of legislation but also a list of fundamental rights of individuals or individual freedoms. In this way, the Constitution outlines principles, directions, and limits for the content of future laws. The Constitution is then not only a procedural rule but also a substantive rule (Kelsen, 1928). Considered from its subject matter and content, the Constitution determines the legal standards under which governors exercise the authority of the State. It is difficult to decide on the scope of a material Constitution very precisely. It is generally considered to include the rules that govern political institutions as well as, in the spirit of modern liberal constitutionalism, the essential rights, and freedoms granted to individuals. These rules may have a very different status: they may or may not be or have a differentiated and overlapping legal value. In the real definition that highlights the soft substance of the Constitution, it is perceived sometimes as a vital principle of the State, sometimes as a privileged instrument of the social institution, sometimes as an instrument for integrating law and facts (Moderne, 2006). In general, formal conceptions of the Constitution admit the idea of revision more easily than real definitions.

The distinction based on flexibility or inflexibility also plays an essential role in the revision of the Constitution. The difference is based on the ease with which the Constitution can be revised. But there is no radical opposition, only that some Constitutions are more flexible than others ${ }^{5}$. Flexible constitutions are 
those that can be amended according to the forms and procedures of ordinary law, i.e., by the adoption of texts by simple majorities in parliament (Bell, 2000). Parliament, having sovereign power, legislates without really distinguishing between legislative matters stricto sensu and constitutional issues. The superiority of constitutional law over ordinary law does not lead to any practical legal consequences (Gicquel \& Gicquel, 2009). Indeed, in the revision of the flexible law, the legislator is trusted, and in this system, there is not always a hierarchy between the formal Constitution and other legal rules. Simple acts can revise these forms of flexible constitutions. That was the case, for example, of the French constitutional charters of 1814 and 1830 or the Italian Albertine Statute of 1848 . As for the rigid Constitutions, they can only be amended according to particular forms or procedures, different from those used for ordinary laws. The legal superiority of the constitutional text over ordinary law is then ensured (Le Divelec, 2015).

The theory of constitutional rigidity developed by authors such as DICEY and BRYCE has nuanced connotations. Thus (Bryce, 1900) essentially attributes the stiffness of the Constitution to the fact that constitutional norms are beyond the reach of parliaments and that their amendment is devolved to an ad hoc body. The rigidity of the Constitution makes it possible to separate the power of the sovereign (original constituent power) from that of the legislator (derived constituent power) in matters of constitutional revision. Professor Lord DICEY assimilates rigidity to the procedural specificities of the constitution review process.

In comparative constitutional law, the reality is often between complete flexibility and rigidity, with a scale of stiffness that varies according to political regimes and established review procedures. Total flexibility trivializes the legal action that is the Constitution, while absolute rigidity would block any evolution and generate pernicious alternatives to revision. The ideal is therefore modulated rigidity with a variable gradation according to contextual specificities (Fall, 2011).

Moreover, the philosophy of the revision must also be understood according to the legal culture of each State and each political society. In European constitutional practice, for example, the review of the Constitution is part of the register of normality or even banality. In the countries of Europe, the philosophy of the change of the Constitution is guided by the evolution of political-legal, socioeconomic ideas which sometimes have to be printed and retraced in the Basic Law. For example, progress in human rights, decentralization movements, and the need for normative and institutional adjustments of state organization to the dynamics of European integration are accompanied by constitutional revisions in some European states (Lavroff, 2008R27). In this system, the adaptation of the Constitution to new political situations is the work of the original constituent ${ }^{5}$ For example, the Malian Constitution of 1992 is more difficult to revise than the Senegalese Constitution of 22 January 2001; the French Constitution of 1958 is easy to revise than the US Constitution of 1787 etc. 
power. Indeed, it is the one that provides for constitutional revision in the already established Constitution. Frequent changes of the Constitution do not fundamentally challenge the rigid nature of the Constitution. Therefore, the increase in Constitution modifications, which is often interpreted as a form of infringement of Constitution rigidity, is only an infringement of Constitution stability. Normative stiffness is in no way in question (Ardant, 1999).

Unlike the European case, in the constitutional systems on the American continent, the most representative of which is that of the United States, constitutional amendments are sacred. Indeed, the almost biblical reputation of the Supreme Charter feeds the myth of its perfection. The holy text is timeless and immutable but adaptable to each time. This sacredness of the Constitution has proved possible thanks to the power of interpretation of the Constitution which the Supreme Court of the United States of America has acquired, since the founding decisions of its jurisprudence (Zoller, 1994). The Supreme Court of the United States, through an audacious use of constitutional interpretation, has established itself as the pontiff of the adaptation of the Constitution to the developments of American society (Weber, 2004). In this regard, Chief Justice Evan HUGHES stated in 1936 that the Constitution of the United States of America is today what the Supreme Court says it is (Freund, 1967).

On the African continent, the philosophy of constitutional revision is closer to the European culture from which most states were inspired when they gained independence (Lavroff, 2008). In African countries, the review of the Constitution is part of the routine or even commonplace because the States of the African continent, also if they almost all have rigid Constitutions whose amendments require particular procedures, in practice this constitutional rigidity is relegated to the second place ${ }^{6}$. Formal and formal rigidity often gives way to ideological and malleable stiffness. In other words, the "rigidity of constitutional mechanisms" contrasts with the "paradoxical inflation of revisions" in Africa (Amougou, 2007). To such an extent that on the eve of the constitutional renewal in Africa, Gonidec (Gonidec, 1988) reviewing thirty years of constitutional practice on the black continent, was already questioning the very usefulness of African constitutions, thus raising his doubts about the evolution of African constitutionalism. Thirty years during which the theses of the rejection of constitutionalism on the one hand and the decline of constitutionalism, on the other hand, coexisted in thirty years of independence, the constitutional fever characterized by the sacralization of the Constitution and constitutional fetishism quickly gave way to justify Constitution instability (Ahanhanzo Glele, 1982) variously. These multiple modifications of constitutional provisions in Africa produce the devaluation of the constitutional writing of which we are talking and

${ }^{6}$ In this subject, Senegal, Niger, Burkina Faso, Burundi, Benin, can be cited as examples of countries where the Constitutions were often revised with a procedural banality. In these countries, practice shows that the legal dikes erected to protect the tranquility and stability of the Basic Law are ineffective, in any case, not dissuasive. Unwanted and opportunistic changes to the Constitution are often made by different political regimes. 
even of constitutionalism in general. For Conac (1983), in Africa, more than anywhere else, the Constitution is linked to the person of the Head of State who gives life to the institutions that are his tool, the instruments of his political strategy.

The Constitution, by its existence, as opposed to arbitrariness in that it defines a State governed by the principle of the rule of law where it is only possible to do what is by the provisions it lays down (Pactet, 2003). It is in this sense that constitutionalism has historically played a significant role in limiting power in all states where a constitution exists. Indeed, in its classical conception, constitutionalism is considered as a means of restricting the ability of rulers. The idea of limited power is too fundamentally in the system of the rule of law. Limiting power often requires two mechanisms to this end: the revision of a Constitution at the top of the legal system and the definition of a set of rights and freedoms to protect citizens from arbitrary government. This primacy of the Constitution according to Hans Kelsen's classic scheme also presupposes the absolute stability of the Constitution (Guillaume, 1946).

That raises the question of what are the procedures for revising the Constitution in the different constitutional systems. Are constitutional amendments always in line with the consolidation of democracy, the rule of law and human rights? Are there any limitations and possibly a legal dike to constitutional amendments? What specifies the question of constitutional revisions in the science of constitutional law? In other words, what are the particularities of the production of the constitutional change?

From these revealing central questions emerges the interest of the subject. Often established for eternity or continuity, Constitutions through their revision systems allow each people to root their political ideologies at a time of their political evolution. In cyclical development, each generation is obliged to leave a political legacy to future generations that guarantee maximum legal stability. The process of making revisions, which is a priori laid down by the Constitution, is also a means of achieving this objective of constitutional security. However, an analysis of the content of modern constitutional revisions reveals several categories. Thus, there would be no consolidating and adverse changes of democracy regardless of the state, or legal system taken in isolation. A countervailing power is required when the revision of the Constitution attempt to devalue the Constitution itself, the democracy or the rule of law. The constitutional judge whose role is to protect the entire political system and human rights must play the role of counter-power.

For objectivity, we did not consider it necessary to give ourselves a spatial limit to our study in order not to reduce our field of vision. That will allow us to be mobile in our arguments at any time to justify our legal and political discussions on the different constitutional systems. In short, the study seeks, in a perspective of useful comparison to having benchmarks to consolidate or to relativize this or that data of the analysis of our overall problems, to account for the critical content of the revision of the Constitution in constitutionalism. Thus, the elements 
governing the revision procedure, the limits and typologies, and the judicial review of constitutional changes will be addressed in this study.

\section{The Process for Revising the Constitution, a Process Defined Differently According to the Constitutional Systems of the States}

In the general sense, a method is a series of acts that must be performed to reach a decision. The establishment of a system for revising the Constitution presupposes that it has several actors who share decision-making power, or who intervene in other capacities, for example in an advisory role. About constitutional amendments, in principle, every Constitution lays down the procedure for its revision. Through the Constitutions, a diversity of solutions appears, this competence can be shared between several bodies and require several steps. From the analysis of the different constitutional systems, it can be seen that the procedure for revising the Constitution includes the initiative and the drafting and adoption of the Constitution.

\subsection{Initiatives for Constitutional Revisions Shared by Several Actors}

If there is one constant in the history of political life, it is its continued institutionalization. From the absolute leader of the first human groups to power based on courage, skill or wisdom, to the journey to contemporary parliaments, legitimized by-election and subject to binding and complicated rules.

The institutionalization of political life here means the establishment of structures and mechanisms, organizing and supervising the exercise of power and the struggles that its conquest, control, and defense generate. During this evolution, the rules of the game gradually replaced the simple balance of power. Thus, imitated and repeated behaviors, to which we have almost instinctively conformed, have become traditions, customs whose respect grows obligatory for all. For greater certainty and certainty, the results of practice have been written into texts of which the modern Constitutions are the latest state. At the same time, actors have asserted themselves and multiplied, holding a fragment of power and assigned to specific functions; nowadays, they are heads of state and government, ministers, parliamentarians and judges who exercise power by the delegation of the people. Also, the citizens themselves, called upon to choose who will speak on their behalf and sometimes directly involved in decision-making, through referendums or petitions, have become actors in political life in their turn. By this observation and because of the place of the Constitutions in a political system, the initiative for its revision is divided between the executive, legislative and people in most modern Constitutions.

\subsubsection{Systems Granting the Initiative of Constitutional Change to the Executive Branch}

In some political orders, it is considered that entrusting the enterprise for the 
amendment of the Constitution to the executive branch is one of the best possible solutions because it is just because it is in a position to initiate the necessary improvements. Thus, article 89 of the French Constitution of 1958 provides that "The initiative to revise the Constitution belong concurrently to the President of the Republic on the proposal of the Prime Minister and the members of Parliament." The President of the Republic may, therefore, initiate a procedure to revise the Constitution on the proposal of his Prime Minister. In this case, we can talk about a project constitutional amendment. In principle, therefore, it is the Prime Minister who is at the origin of the procedure in the French system. This condition has long been quite formal, in the sense that because of the relations established until 1986 between the President of the Republic and the former, even if the latter indeed made the request, the initiative came from the President. The situation only changes when the two men come from different political camps in the event of political cohabitation. The President of the Republic cannot, therefore, force the Prime Minister to draw up a proposal for constitutional revision. In any case, the initiative is shared between the two heads of the executive in France.

In Senegal, the procedure for revising the Constitution is governed by article 103 of the Constitution of 22 January 2001, which provides in essence that the initiative to amend the Constitution belongs concurrently to the Head of State and the deputies. ${ }^{8}$ The Prime Minister may propose to the President of the Republic a revision of the Constitution. In this case, unlike the French case, the power to learn an initiative to revise the Constitution is first and foremost a nonconditional attribute of the President of the Republic. That is to say, the head of State may initiate a constitutional review procedure of his own accord; this power is not linked to a prior wish of the Prime Minister. By the general economy of presidential to which Senegal has subscribed since 1963, the procedure for revising the Constitution reflects the institutional and political pre-eminence of the President of the Republic. Although the constitutional text confers the power to trigger the revision of the Basic Law simultaneously on the Head of State and the deputies, practice shows real domination, a practical monopoly chief of State in this matter. The head of State determines and conducts the policy of the nation in general and constitutional policy in particular. Its monopoly on the initiative of constitutional laws is only one component of its control of the extensive action. Since rules are the translation of public policies-for which the President is responsible for the design, implementation, and coordination-the presidential power to promote laws is consistent with the political and legal rationality of the system. In other African countries such as Chad, the initiative to trigger the revision of the Constitution belongs to the President of the Republic, after a decision taken by the Council of Ministers. ${ }^{9}$ In Mali, the 1992 Constitution also grants the power to review the Constitution to the executive branch through the ${ }^{7}$ See French Constitution of 3 June 1958, art 89.

${ }^{8}$ See Constitution of Senegal of 22 January 2001, art 103.

${ }^{9}$ See Constitution of Chad of 31 March 1996 revised, art 224. 
President of the Republic. ${ }^{10}$ In the same vein, in Brazil, the President of the Republic has the power to initiate any constitutional amendment that he deems appropriate to the new orientations of political life. ${ }^{11}$

In some countries, the right to initiated Constitution modification is vested in the legislative branch. It is worth studying some examples of this in comparative law.

\subsubsection{The Parliamentary Initiative to Amend the Constitution}

Parliamentarians, representatives of the Nation, also have the right to initiate the revision of the Constitution. The Constitutions generally grant them this power according to the democratic culture of each country. Indeed, the modalities of this legislative power to review the Constitution are organized differently in constitutionalism. For example, in Brazil, constitutional amendments can be proposed by half of the state legislatures. The 1988 Brazilian Constitution provides that it may be amended on the proposal of at least one-third of the members of the Chamber of Assembly or the Senate. ${ }^{12}$ In France, the 1848 Constitution envisaged a parliamentary initiative to revise the Constitution. Article 11 of the said Constitution provided in substance that when, in the last year of a legislature, the National Assembly has expressed the wish that the Constitution be amended in whole or in part, this revision shall be carried out. ${ }^{13}$ In the same way, in the United States, two-thirds of the legislative chambers of the federal states can submit a proposal for a constitutional amendment to Congress. ${ }^{14}$ This proposed revision makes it an obligation of Congress to provoke a Federal constituent assembly. In the Federal Republic of Ethiopia, one-third of the parliaments of the federated states may propose constitutional revision under the Constitution. In the Federal Republic of Ethiopia, one-third of the parliaments of the Federated States can suggest legal review under the Constitution. For that, the Ethiopian Constitution provides that: "Any proposal for constitutional amendment, if supported by two-thirds majority vote in the House of Peoples' Representatives, or by a two-thirds majority vote in the House of the Federation or when one-third of the State Councils of the member States of the Federation, by a majority vote in each Council have supported it; shall be submitted for discussion and decision to the general public and to those whom the amendment of the Constitution concerns". ${ }^{15}$ In China, according to article 62 of the Constitution, the National People's Congress has the function of amending the Constitution. ${ }^{16}$ The Permanent Committee of the National People's Congress or at least one-fifth of the deputies may make proposals for constitutional reforms.

Another example of constitutional revision initiated by parliamentarians is Spain, where the legislative assemblies of autonomous entities can propose con-

\footnotetext{
${ }^{10}$ See Constitution of Mali of 25 February 1992, art 118.

${ }^{11}$ See Constitution of Brazil of 5 October 1988, art 60.

${ }^{12}$ See Constitution of Brazil of 5 October 1988, art 60.

${ }^{13}$ See French Constitution of 4 November 1848, art 111.

${ }^{14}$ See Constitution of the United States of 17 September 1787, art V.

${ }^{15}$ See Constitution of the Federal Democratic Republic of Ethiopia, art 104.

${ }^{16}$ See Constitution of the People's Republic of China of December 4, 1982, art 62.
} 
stitutional amendments. In this case, the initiative for constitutional change is carried out by the provisions of article 87 of the Constitution. Indeed, Article 166 of the Spanish Constitution on constitutional change refers to the provisions of Article 87. As a result, the ordinary legislative procedure and the constitutional revision procedure are uniforms about the authorities having the initiative. Also, in Russia ${ }^{17}$, France $^{18}$, Mali $^{19}$, the legislative assemblies can be at the origin of constitutional revisions.

In some countries, citizens can also play the role of initiators of the constitutional review process in parallel with political institutions (President of the Republic, government and parliament).

\subsubsection{The Popular Initiative to Amend the Constitution}

Citizens can take action themselves to request a revision of the Constitution. The hypothesis is quite rare and prohibited in some Constitutions ${ }^{20}$, but it exists in comparative constitutional law. Since the Constitution review process is, in principle, concerned with satisfying and taking into account the real needs of political and social life, it is normal for citizens to be able to petition for constitutional review. To this purpose, there are several ways to institutionalize popular participation in the revision of a constitution. Minimum participation is to allow citizens to play a formal role in proposing changes to parliaments in some countries. Citizens play an important role in constitutional amendments in states with such solutions. Thus, in Switzerland, a constitutional revision procedure can be triggered by a portion of citizens through a revision petition. In other words, 100,000 citizens by their signatures can demand an amendment to the Federal Constitution. This petition may concern a partial or total revision of the Constitution submitted to the referendum. ${ }^{21}$ The procedure then opens with a minimum number of signatures, which obliges the assemblies to examine the draft revision of the signatories and provide it to a referendum.

The constituent powers of several Russian federal states are moving in the same direction by granting their people the right to initiate the revision of the Constitution. Such is the case in Ingushetia State, where a petition of 10,000 signatures is sufficient to request a constitutional review. That is also the case in the Sverdlovsk region, where five thousand citizens can file a petition for revision.

In France, the 1793 Constitution also provided an opportunity for citizens to request a constitutional review. The primary assemblies of citizens ${ }^{22}$ could require the convening of a convention or revision assembly. Here, if in half of the departments, plus one, one-tenth of the primary meetings of each of them, duly

\footnotetext{
${ }^{17}$ See Constitution of Russia of 12 December 1993, art 134.

${ }^{18}$ See French Constitution of 1958, art 89.

${ }^{19}$ See Malian Constitution of 25 February 1992, art 118.

${ }^{20}$ On this question, for example, in some countries such as Mali, the United States, Mexico, Brazil, Germany, Ethiopia, and China etc. the constituent power does not grant citizens the right of initiative to review.

${ }^{21}$ See Swiss Constitution of 18 April 1999, art 138 and 139.

${ }^{22}$ According to article 11 of the 1793 Constitution, the Primary Citizens' Assemblies were composed of citizens who had been domiciled in each canton for six months.
} 
formed, request the revision of the constitutional act, or the change of some of these articles, the Legislative Body is required to convene all the primary assemblies of the Republic, to know if there is a need for a national convention. ${ }^{23}$ In Burkina Faso, a fraction of at least thirty thousand persons with the right to vote may submit a petition to the National Assembly constituting a proposal to amend the Constitution. ${ }^{24}$ When the constitutional revision initiative is launched, the question then arises as to how the content of the act of revision will be drafted and approved.

\section{The Existence of Various Techniques for the Elaboration and Approval of the Material of the Constitutional Amendment}

In practice, the political institution or the holder of the right to trigger the review of the Constitution is not the one that brings it to an end. That raises the question of the preparation and adoption of the draft revised Constitution. On this basis, the comparative study of the different legal systems allows us to have a range of solutions. If on the first one there is almost no specific constitutional framework, for the second one there are no formal constitutions.

\subsection{Techniques for the Elaboration of the Revision of the Constitution}

On this subject, legal practices have developed several mechanisms for solutions. These practices often result in the establishment of a Constitutional Review Commission that can play different roles in the Constitution review process. The members of the structures responsible for drafting the content of the constitutional revision are chosen in various ways. Under these conditions, those responsible for establishing the constitutional reform process have the onerous task of determining whether the use of commissions or assemblies should be permitted or required (Gutiérrez González, 2005). It is not uncommon in comparative law to see the establishment of commissions to which the role of drafting the preliminary draft of the constitutional revision that should lead to the successful completion of the reform of the Constitution is entrusted. Malian legal practice is abundant in this area. At least from 1992 to the present day, several structures have been put in place to develop the content of the draft revisions that the various presidents of the Republic wanted to carry out during their terms of office.

The President of the Republic Alpha Oumar KONARE, in 2000, organized regional consultations and a National Political Forum to reform the 1992 Malian Constitution. The recommendations resulting from these activities were the subject of a draft law for constitutional revision, which was adopted by the deputies on 21 July 2000. In 2008, the President of the Republic Amadou Toumani TOURE appointed Minister Daba DIAWARA by Decree No. 08-072 /P-RM of

${ }^{23}$ See French Constitution of 24 June 1793, art 11.

${ }^{24}$ See Constitution of Burkina Faso of 02 June 1991, art 161. 
07 February 2008 to lead the reflection for the consolidation of democracy in Mali. ${ }^{25}$ To achieve this objective, the President sent Minister DIAWARA Mission Letter $\mathrm{N}^{\circ} 0000000030 / \mathrm{PRM}$ dated 20 February 2008 containing the points on which he wanted to make a reform. Thus, in this mission letter, the President wrote: "I am convinced that the vitality of a democracy lies in its ability to question itself constantly. For that reason, I wanted to entrust you with the task of reflecting on our electoral system and the status of the opposition as well as on the organization and functioning of the institutions of the Republic, to make me proposals aimed at strengthening the legal framework and the practice of democracy". ${ }^{26}$ This committee of experts responsible for drafting the constitutional amendment submitted a working report in September as a draft Constitution. In April $2016^{27}$ and $2019^{28}$, the President of the Republic and the Prime Minister of Mali respectively issued Decrees establishing a Committee of Experts for the revision of the Constitution on 25 February 1992.

In the United States, some states entrust the drafting of the draft revised Constitution to review commissions and assemblies. The Utah State Legislative Chamber has established a Constitutional Review Commission, whose members continue to be responsible for recommending constitutional amendments that will then be considered by the Legislative Chamber. Over the past decades, this committee has introduced several changes that have been accepted, including a modification to clarify the succession process for the position of governor. In 1968, Florida created a Constitutional Review Commission. The Governor and the Legislative Chamber appoint the members of this commission and meet every 20 years to propose Constitution modification to the population. Subsequently, in 1988, Florida created the Budget and Tax Reform Commission, which also meets every 20 years and may submit constitutional changes specifically related to tax issues.

In Argentina, the reform of provincial constitutions often involves constituent or reform assemblies, which are convened when two-thirds of rural legislators call for changes. They draft the draft constitutional reform.

In Mexico, the primary method of amending state constitutions is through a permanent constituent Congress convened by a two-thirds vote of state legislators. This Congress has the power to draft reforms that generally require the approval of a majority of municipal councils (Gutiérrez González, 2005).

In China, on 27 March 2003, a constitutional review group was set up, led by $\mathrm{Wu}$ Bangguo, the new chairman of the standing committee of the National People's Congress. ${ }^{29}$ This review group was placed directly under the authority ${ }^{25}$ DECREE N $08-072$ /P-RM OF 07 February 2008 of the Presidency of the Republic of Mali; appointing a person to lead the reflection on the consolidation of democracy in Mali.

${ }^{26}$ Presidency of the Republic of Mali, Mission Letter N $0000000030 /$ PRM dated 20 February 2008.

${ }^{27}$ Decree No. 0235/PM-RM of 20 April 2016 of the Presidency of the Republic of Mali; establishing a Committee of Experts for the revision of the Constitution of 25 February 1992.

${ }^{28}$ Primature Republic of Mali, Decree 2019-0015 of 4 September 2019 establishing a Committee of Experts for the revision of the Constitution.

${ }^{29}$ See The Revision Of The Constitution In The Prc. (n.d.). Retrieved from

https://journals.openedition.org/chinaperspectives/2922 
of the Standing Committee of the Political Bureau of the Chinese Communist Party. At the same time, the latter is developing the principles for constitutional revision that led to the 2004 Constitution reforms (Jianfu, 2004).

In Senegal, by Decree No. 2013-730 of 28 May 2013, a National Commission for Institutional Reform was established. Its general mission was to organize a broad national consultation on the institutional reforms to be initiated in the short, medium and long term to propose changes in line with the status of the democratic state and aspirations for a better future. The work of the said commission will lead to the constitutional reform of 20 March 2016 in Senegal. After its elaboration, the question of the adoption and approval of the text of the revision of the constitution must be resolved.

\subsection{The Existence of a Plurality of Methods for Adopting and Approving the Change of the Constitution}

One of the possibilities available to the original Constituent Power to provide a Constitution with at least partial rigidity is to revise a severe and complicated procedure. This search for solemnity and complexity in the modalities of review is found in almost all the Constitutions. Sobriety in constitutional production originated in the 18th century. The Men of that time readily considered a new Constitution enacted by national sovereignty as a real renewal of the social contract (Esmein, 1906). That is why it is necessary to draft constitutional clauses in the most solemn and complete form (Esmein, 1906). Solemnity may also result from the greater or lesser number of persons called upon to speak or, at least, to participate in the constitutional review. As such, the implementation of the referendum certainly appears to be the completed form of solemnity. The solemnity of the procedure is all the more marked as the number of those called upon to rule on the possible constitutional amendment is greater. In this respect, it could be said that the most rigid Constitutions are those that postulate the implementation of a referendum considered as a direct recourse to the original constituent power which is the people (Laboulaye, 1872). By studying comparative constitutionalism, we realize that the systems of adoption and approval of constitutional revisions vary according to political ideology. In general, there are legal systems that opt for the legislative assembly method for the final passage of the constitutional change; and others that require a referendum.

\subsubsection{The Parliamentary Way for the Approval of the Constitution Modification}

The ease or difficulty of having constitutional amendments approved by the legislature is one of the main elements of protecting the Constitution. The reading of the Constitutions shows the requirement of a simple or qualified majority in the legislative chamber to complete the procedure for the revision of the Constitution. The conditions that the legislative chamber must approve constitutional amendments by a simple majority, a thin qualified majority or a significant qualified majority contribute to further ensuring the supremacy of the Basic Law. 
The constituent power originating in several States authorizes the approval of constitutional amendments by a qualified majority within the parliament. In other words, the Constitution requires that constitutional amendments be approved by a convincing qualified majority of the members of parliament. In Canada, there are five distinct constitutional amendment procedures. They are provided for in sections 38 to 47 of the Constitution Act, 1982. Each applies to a particular category of constitutional amendments. These are the general formula, the unanimity formula, the bilateral or multilateral formula, the unilateral federal formula and the one-sided provincial formula (Beaudoin \& Thibault, 2004). By the general method of approval of the revision of the Constitution applies when no other procedure is provided for this domain. It requires that the House of Commons adopts the amendment, the Senate and the legislatures of at least seven provinces representing at least $50 \%$ of the population. In some situations, not only must the assemblies agree, but a majority of the members of its Assemblies must be in favor of revising the Constitution. This formula is often referred to as the "7/50" technique (Pelletier, 1996). It must be used, for example, to amend the division of powers or the Canadian Charter of Rights and Freedoms. In China, amendments to the Constitution proposed by the Standing Committee of the National People's Congress or by at least one-fifth of the members of the Assembly are adopted by a two-thirds majority of all members of the Assembly. ${ }^{30}$

In Argentina, the approval of constitutional amendments is even more rigid as they require more than two-thirds of the members of the legislative chamber. In the State of Formosa in Argentina, changes to the Constitution must obtain four-fifths of the votes of the Legislative Chamber for their validation. The constituent of the State of Santiago del Estero provides for the agreement of three-quarters of the members of the Legislative Chamber to carry out a total revision of the Constitution. In Mexico, the primary method of amending state constitutions is through a permanent constituent Congress convened by a two-thirds vote of state legislators. This Congress has the power to draft reforms that generally require the approval of a majority of municipal councils.

Certain constitutions require a two-thirds majority of the members of the legislative assembly to approve any constitutional revision. By way of illustration, the case of Austria and Russia can be highlighted. Indeed, in this country, Article 44 provides that the National Council may only adopt constitutional laws or constitutional provisions contained in ordinary rules in the presence of at least half of its members, and by a two-thirds majority of the votes cast In Austria, in addition to the qualified majority, a qualified quorum is also required..$^{31}$ For Russia, the Constitutional Assembly is responsible for adopting the revision of the Constitution by a two-thirds majority of the votes of all its members. ${ }^{32}$

Alongside the constituent powers that require a substantial majority for the

\footnotetext{
${ }^{30}$ See Constitution of the People's Republic of China, art 63.

${ }^{31}$ See the Federal Constitutional Act of 1 October 1920, art 44.

${ }^{32}$ See Constitution of Russia of 12 December 1993, art 145.
} 
approval of constitutional amendments, there are those that make this quota more flexible. In France, the first stage of the revision is none other than the adoption of law under the condition of strict bicameralism. The qualification here consists in the fact that no Assembly prevails over the other, each must vote by a simple majority for an identical text. In Brazil, amendments to provincial constitutions require only the support of three-fifths of the members of the legislative chamber to be valid. In Canada, provincial constitutional laws can be amended with the approval of a simple majority of legislators.

\subsubsection{Approval of the Constitutional Revision by Referendum}

A referendum is a direct vote of all voters in a state or local authority who vote on a legislative or legal proposal at the initiative of the executive branch or citizens, by the procedures defined by law. The draft submitted to the vote is either accepted or rejected. Referendums are a means of obtaining the people's support on major social or institutional issues. Through the referendum, it is the legislating people who decide. In this sense "any law that the people themselves have not ratified is null and void” (Rousseau, 1896). Some Constitutions make a good reception of this perception of (Rousseau, 1896) by providing that the people be involved in approving revisions to the Constitution. The use of referendums to amend the Constitution is either mandatory or optional.

In France, the use of constitutional referendums is provided for in the 1958 Constitution and is a direct consequence of the sovereignty of the people. According to article 89 of the Constitution, the project of revision must be voted on by both assemblies in identical terms. The change is final after having been approved by referendum; however, the same article states that the draft revision is not presented to the referendum when the head of State decides to submit it to the Parliament convened in Congress. ${ }^{33}$ For the drafters of the 1958 French Constitution, it is not appropriate to require in all cases of constitutional revision the use of the long, cumbersome and costly referendum formula, particularly when the modification concerns legal, technical aspects or is urgent.

In Africa, some states inspired by the French system do the same by making the use of referendums optional or mandatory for the approval of constitutional amendments. Among these States is Benin, whose 1990 Constitution provides that "the revision is only acquired after having been approved by referendum" unless the draft revision in question is approved by a majority of four-fifths of the members of the National Assembly. ${ }^{34}$ In Burkina Faso, the Constitution of 11 June 1991 states that the draft revision is adopted without recourse to a referendum if it is approved by a three-quarters majority of the members of Parliament convened in Congress by the President of the Republic. ${ }^{35}$ The Constitution of Niger agrees in the same sense by stipulating that the final approval of the revision of the Constitution is made by referendum unless it has been approved by a

${ }^{33}$ See French Constitution of 3 June 1958, art 89

${ }^{34}$ See Constitution of Benin of 11 December 1990, art 155.

${ }^{35}$ See Constitution of Burkina Faso of 27 January 1997, art 164. 
majority of four-fifths of the deputies of the National Assembly. ${ }^{36}$ In Senegal, the final approval of the revision can be made by the people through a referendum. According to the Constitution, the revision is final after having been approved by referendum unless the President of the State decides to submit it to the National Assembly alone. In Sudan, a popular referendum for ratification is required if the National Assembly approves an amendment that is "against the basic principles" of the constitutional system. ${ }^{37}$

It should also be mentioned that other constitutions in Africa make the referendum route mandatory as a means of final approval of constitutional revisions. Mali and Chad rank in this group. The Malian constituent power provides that the constitutional review is last only after it has been approved by referendum. ${ }^{38}$ In Chad, except for constitutional amendment of a technical nature, all other forms of changes are only valid after their popular approval. ${ }^{39}$ In these two African states, each constitutional amendment must be ratified by the people, regardless of its scope or circumstances.

In a country like Austria, the Constitution sets a condition for the intervention of the people to approve a constitutional amendment. Thus, a total revision of the Constitution must be ratified using a national popular referendum; a partial correction must be the subject of a referendum if one-third of the members of either legislative chamber request it.

The Constitutions analyzed here all appear to meet the definition of a rigid Constitution in constitutional review procedures. The complexity of legal production and Constitution rigidity consists in the need to use an exceptional system, different from the ordinary legislative process, to amend the supreme norm of the domestic legal order. The need to protect the Constitution explains why the constituents have opted for more complex procedures for constitutional revision. The option for written form, the quasi-generalized institution of bicameralism and solemn and particular revision modalities, demonstrate the confirmation of Constitution rigidity in constitutionalism. It can be seen here that the existence of these various techniques for the elaboration and approval of the content of the constitutional revision is intended to protect the Constitution against abusive reforms. Indeed, the requirements related to the procedure for the elaboration and approval of the content of the revision of the Constitution make it possible to avoid the trivialization of constitutional reforms. The protection of the Constitution is guaranteed when the conditions to be respected for its revision are heavy. Otherwise, it would be easy to undermine its provisions through constitutional reforms with a purely subjective or anti-democratic purpose. This complexity of the procedure for revising the Constitutions, combined with the revision limits imposed on the derived constituent power, ensures the security Constitution rules.

\footnotetext{
${ }^{36}$ See Constitution of Senegal of 12 May 1996, art 124.

${ }^{37}$ See Constitution of Sudan of 1 July 1998, art 139.

${ }^{38}$ See Constitution of Mali of 25 February 1992, art 118.

${ }^{39}$ See Constitution of Chad of 14 April 1996, art 224.
} 


\section{The Boundaries and Typologies of Constitutional Revisions}

As the Constitution is the legal instrument containing the will of the sovereign people in this respect, its review is strictly regulated and often prohibited. In constitutional systems, the constituent power has provided for limitations on the change of the Constitution. These formal or circumstantial limits must be respected when making constitutional amendments. However, in some countries, they are challenged by the constituent power that is often derived from, and often complicit with, political authority. The violation of the prohibitions on review can, therefore, harm democracy, the rule of law and public freedoms.

\subsection{Prohibitions on Revision in Constitutional Texts}

In analyzing the constitutional documents of the various countries, it is clear that the constitutions themselves set limits to their modification. That is, there are limits to Constitution review that are expressly set out in Constitution norms. These limits can be divided into two main categories. The Constitutions prohibit their revision on specific numbers of matters or during a certain period of the life of the nation. Thus, we have the absolute limitations and the precise limitations of constitutional revision.

\subsubsection{Absolute Prohibitions of Medication of the Constitution or Elements That Are Not Subject to Amendment}

The practice of constitutional changes shows that the drafters of certain constitutions exclude from the shift of certain provisions of the Constitution text. In other words, in some legal systems, there are intangible provisions that cannot be reviewed under the Constitution review procedure. The constituents generally declare nonmodifiable the principles they consider essential for the existence of the political system established in the Constitution. The purpose of these prohibitions is therefore to protect the fundamental foundations of the state system. The field of protection of the republican form of government or state is more concerned with material prohibitions to revise the Constitution. In France, for example, since the law of 14 August 1884, the Constitutions prohibit rewriting the republican form of government. This situation is linked to French constitutional developments. The founding tenets of the 3rd French Republic remained open for monarchical restoration. That is one of the conditions for their acceptance by the royalist deputies. In line with the stabilization of the political and Republican consensus, the reform of 14 August 1884 completes article 8, paragraph 3, of the Constitutional Act of 25 February 1875 on constitutional revision. It was then provided in this text that the republican form of government is unchangeable to prevent any return to the old monarchical or imperial policies. Despite contradictory doctrinaire debates, France retains the prohibition to change the republican form of its government in its 1958 Constitution still in 
force. ${ }^{40}$ Post-war Italy, which has just abolished the Monarchy, also provides for a ban on undermining the republican form of government. ${ }^{41}$ That is because at that time Italy was very close to France in its constitutional conceptions.

In Turkey, Article $1^{42}$ of the Constitution provides that the form of the State is a Republic, as well as the characteristics of the Republic specified in Article $2^{43}$ and those of Article 3 shall not be revised, nor their proposed revision. The same principle of prohibition of the republican form of the State is also visible in the African constitutions, which are mainly inspired by French institutional practice. ${ }^{44}$

In Germany, the material limits to constitutional revision concern, in addition to the Federal nature of the State, a long list of rights that are not subject to review. Thus, Article 79 of the German Constitution states that any change of the Basic Law that would affect the organization of the Federation in the Länder or the principle of the participation of the Länder in legislation is prohibited. The same provision adds that the laws set out in Articles 1 and 20 of the Constitution cannot be amended. ${ }^{45}$ After the fall of Nazism, the new Federal Republic of Germany wanted to give excellent protection to the system of democracy, the rule of law and federalism by excluding from any constitutional revision the part of the constitution relating to these principles. For example, the dignity of the human being, the right to civil disobedience, are intangible in Germany.

The Congolese, Algerian and Cameroonian constitutions provide for material limitations on the revision of the Constitution. In the Republic of Congo, the 1992 Constitution provides that the republican form, the secular nature of the State and the number of terms of office of the President of the Republic may not be revised. ${ }^{46}$ In Algeria ${ }^{47}$ and Cameroon ${ }^{48}$, the constitutional provisions relating to territorial integrity are not amendable.

The Constitution of some monarchical countries declares the monarchical form of the State to be intangible. Thus, in Morocco, article 175 of the Constitution provides that no constitutional amendment may concern the provisions relating to the monarchical form of the State. ${ }^{49}$ Similarly, in the past, the Iranian Constitutions of 1906 and the Greek Constitutions of 1952 prohibited the revision of the monarchical form of the State. The preservation of the constitutional

\footnotetext{
${ }^{40}$ See French Constitution of 1958 , art 89.

${ }^{41}$ See Constitution of Italy of 27 December 1947, art 139.

${ }^{42}$ See Constitution of Turkey of 7 November 1982, art 1.

${ }^{43}$ According to Article 2 of the Constitution, the Republic of Turkey is a democratic, secular and social State governed by the rule of law, respectful of human rights, in a concept of social peace, national solidarity and justice, committed to Atatürk nationalism and based on the fundamental principles expressed in the preamble. So no constitutional revision can call these elements into question. ${ }^{44}$ See in this regard the constitutions of Algeria (art 195); Cameroon (art 37); ivory coast(art 73); Central African Republic (art 42); Equatorial Guinea (art. 59); Gabon (art 85); Madagascar (art 108); Mali (art 118); Senegal (art 89); and Togo (art 53).

${ }^{45}$ See Constitution of German of 23 May 1949, art 79.

${ }^{46}$ See Constitution of the Republic of Congo of 15 March 1992, revised on 24 October 1997, art 178

${ }^{47}$ See Constitution of Algeria of 22 November 1976, art 195.

${ }^{48}$ See Constitution of Cameroon of 2 June 1972, art 64.

${ }^{49}$ See Constitution of Morocco of 29 July 2011, art 175.
} 
rule can also be expressed through a prohibition on revising the Constitution during crucial periods of national political life.

\subsubsection{Circumstantial Prohibitions to Amend the Constitution or Prohibitions ratione temporis}

In addition to the material prohibitions on revision, certain constitutions provide for temporal limitations. In other words, the Constitutions prohibit their change for a certain period. The idea here is not to protect specific fundamental data of the legal order but to prevent a constitutional amendment from taking place at the moment when the people are not free to make their decisions. In such situations, we are talking about time limits on the power of constitutional review. Sometimes the revision of the Constitution is subject to the expiry of a time limit set by the Constitution or particular security, political and other situations prevent any idea of constitutional revision. Here again, the cross-referenced analysis of a few Constitution orders allows us to highlight some illustrative examples.

Firstly, it happens that the revision of the Constitution is sometimes subject to the expression of a persistent will, of a prolonged need. We do not want constitutional change to occur as a result of opportunistic or cyclical considerations. Thus, article 284 of the Constitution of Portugal provides that the Assembly may revise the Constitution only " 5 years after the date of publication of the last revision law" ${ }^{50}$ In the past, we can also mention the French Constitution of 1791 according to which the revision can only take place following a wish expressed by three successive legislatures and then by a vote of a Special Revision Assembly. ${ }^{51}$ Among the three chambers that may propose changes, the first two will only deal with this subject in the last two months of their previous session. The third legislature at the end of its first annual session or the beginning of the second will decide on the matter. Similarly, the 1787 Constitution of the United States prohibited the revision of the first and fourth clauses of the ninth section of the first article until 1808. ${ }^{52}$ The logic is followed by the 1967 Constitution of Paraguay, which prohibits its complete revision before ten years have elapsed, and its partial modification before five years from its publication. ${ }^{53}$

Secondly, it happens that under certain circumstances the Constitutions prohibit their reformation. These forms of prohibitions are provided to protect the Constitution during critical periods in the life of the nation. In France, the 1946 and 1958 constitutions drew lessons from the democratic resignation of the National Assembly after the debacle of 1940 by prohibiting any constitutional revision when territorial integrity is compromised. Through colonization, this prohibition is also found in the Constitutions of some former French colonies in Africa. For example, article 118 of the 1992 Malian Constitution prohibits amending the Constitution when foreign forces threaten the integrity of the na-

\footnotetext{
${ }^{50}$ See Constitution of Portugal of 2 April 1976, art 284.

${ }^{51}$ See French Constitution of 3 September 1791, art 2.

${ }^{52}$ See Constitution of the United States of 17 September 1787, art 5.

${ }^{53}$ See Constitution of Paraguay of 25 August 1967, art 219.
} 
tional territory. The same principle is valid in the Constitution of the Ivory Coast in its article 73; that of Gabon in its Article 84 and that of Togo in article 53 of the Constitution.

According to the Spanish Constitution, the revision of the Constitution is prohibited in time of war or when a state of emergency, or a state of emergency, or a state of siege is in force. ${ }^{54}$ In the same vein, the Portuguese constitution specifies that "no act of constitutional revision may be carried out during a state of siege or a state of emergency." 55

Also, the Brazilian Constitution of 5 October 1988 excludes the revision of the Constitution during a state of defense or siege. ${ }^{56}$

In attempting to comment on the limits of constitutional review, it can be said that some are aimed at seeking political and constitutional stability; and others attempt to ensure democratic legality and legitimacy. The purpose of the time limits is to allow a new constitution to be consolidated (Burdeau, 1983). Thus, by limiting the power of constitutional review over time, the Constitution encourages it to take root (Gicquel, 1993). Constitutional revisions when they are completed and promulgated by the competent authority will have an impact on the State's legal system. Under their content, revisions to the Constitution can be classified.

\subsection{The Typology of Constitutional Revisions According to Their Effects}

In principle, the purpose of the revision of the Constitution is to improve political life by adding value. However, it is also possible to see other forms of constitutional revision going in the opposite direction. Indeed, the amendments to the Constitution sometimes strengthen and sometimes weaken the process of democratization of the political system. The objective here is to highlight these two types of constitutional revisions by examining the content of certain constitutional reforms.

\subsubsection{Forms of Constitutional Revision Contributing to the Democratization of Political Life}

In general, the purpose of the constitutional revision is to deepen democracy. Consolidating revisions of democracy are understood to mean constitutional reforms that are more or less consensual, at the very least uncontroversial (Fall, 2011). Progressive in their substance, they enshrine the qualitative improvement of the functioning of institutions and the progress of democracy and the rule of law. When we take a look at constitutional practices, we realize that such kinds of constitutional amendments exist. Thus, it was through a constitutional amendment that marriage between same-sex couples was granted to citizens of the State of California in the United States (Dinan, 2011). In November 2008, it was through the adoption of an amendment to the California Constitution that

${ }^{54}$ See Spanish Constitution of 27 December 1978, art 169

${ }^{55}$ See Portuguese Constitution of 2 April 1976, art 289.

${ }^{56}$ See Constitution of Brazil of 5 October 1988, art 60 . 
citizens overturned the California Supreme Court's decision prohibiting the issuance of new marriage certificates for same-sex couples. In addition to California, it was through constitutional interpretation and amendments that the political issue of same-sex marriage was resolved in many American states. That strengthens the rule of law and the protection of human rights and civil liberties. In the same vein, in late 2008 and early 2009, the Mexican states of Sonora, Baja California, Morelos and Colima adopted constitutional amendments to grant human rights from conception. That was done to prevent the adoption of more liberal abortion laws after the Supreme Court's decision in March 2008 not to recognize a federal right to life from conception. Also in the United States, the Fifteenth Amendment to the Federal Constitution grants the right to vote and stand for election to all Americans without distinction. Indeed, the said constitutional amendment provides that the right of United States citizens to vote will not be denied or limited by the United States, or by any state, on the grounds of race, color, or previous condition of servitude. ${ }^{57}$ The right to vote will be consolidated through the 19th Constitutional Amendment of the 1920s, which stated that: "The right of citizens of the United States to vote may not be denied or restricted by the United States or any of the states by sex." ${ }^{\text {} 58}$ Democratic openness will then give all Americans an equal electoral opportunity and has allowed racial minorities to access elected office.

In France, several constitutional reforms have made it possible to consolidate the institutions of the State and democracy. Thus, in 1962, General de Gaulle, elected President of the Republic four years earlier, wanted to introduce direct universal suffrage during the presidential election to give the newly elected a popular legitimacy.

Its draft constitutional amendment initiating the election of the President of the Republic by direct universal suffrage was adopted with $62 \%$ of the votes in the referendum of 6 November $1962 .{ }^{59}$ This constitutional law will make it possible to directly involve the people in the election of the Head of State. In 1974, the right of referral to the Constitutional Council was granted to parliamentarians by a revision of the 1958 French Constitution.$^{60}$ Sixty deputies or 60 senators can now consult the Constitutional Council before the Head of State promulgates a law. That gives parliamentarians a greater right to control and forces members of the majority to pay more attention to the preparation and drafting of bills. The Constitutional Council emerges from this reform strengthened in its prerogatives, and the Constitution acquires a higher status than the law. That tends to rationalize French parliamentarians. Also in France, in 2000, it was through a revision of the Constitution that the duration of the presidential term ${ }^{57}$ See Reconstruction Era-Wikipedia. (n.d.). Retrieved from https://en.wikipedia.org/wiki/Era_of_Reconstruction.

${ }^{58}$ See the 19 th amendment to the United States Constitution proposed on June 4, 1919 and ratified on August 18, 1920.

${ }^{59}$ See Constitutional Act No. 62-1292 of 6 November 1962 on the election of the President of the Republic by universal suffrage, art 6.

${ }^{60}$ See Constitutional Act No. 74-904 of 29 October 1974 revising article 61 of the 1958 Constitution. 
was reduced from 7 to 5 years. Indeed, on 24 September 2000, the French people adopted with more than $73 \%$ of the "yes" vote a constitutional law submitted to the referendum under Article 89 of the Constitution. ${ }^{61}$ The said law was promulgated on 2 October 2000. It limited the term of office to five years. With this constitutional amendment, it can be said that the political alternation as a pillar of democracy is guaranteed with the shortening of the term of office of the President of the Republic.

In China, the Constitution was amended on 14 March 2004 to include guarantees concerning private property and human rights. That was argued by the government to be progress for Chinese democracy and a sign from Communist Party of China that they recognized the need for change because the booming Chinese economy had created a wealthy new middle class who wanted the protection of their own. ${ }^{62}$ Thus, the Fourth Amendment to the Chinese Constitution provides that the State respect and protect human rights. ${ }^{63}$ The same amendment to the Constitution provides that private property obtained legally shall not be violated. ${ }^{64}$ With this constitutional revision, the People's Republic of China is demonstrating its willingness to give more protection to the human rights contained in the International Covenant on Civil and Political Rights that it signed in 1998. This revision has several significant consequences.

Firstly, it means that China has finally accepted the universality of human rights, after insisting on an "Asian" or "Chinese" conception of the latter. Secondly, it means that the notion of human rights can now be interpreted as including not only fundamental rights as defined in Chapter 2 of the Constitution but also those contained in the international human rights covenants to which China is a signatory. ${ }^{65}$ Finally, insofar as land use rights have been commercialized, compensation for expropriation or requisition by the State is also guaranteed by the revised Constitution; it can be safely stated that in most cases equal protection is now provided to public and private property. That is why, in commenting on the 2004 constitutional reform, Wen Jiabao said that "These amendments of the Chinese constitution are of great importance to the development of China." "We will make serious efforts to carry them out in practice." 66

In Senegal, it is through constitutional amendments that democratic openness has emerged. This openness was first part with the constitutional change ${ }^{61}$ See Constitutional Act No. 2000-964 of 2 October 2000 on the term of office of the President of the Republic.

${ }^{62}$ See Constitution Of The People's Republic Of China-Wikipedia. (n.d.). Retrieved from https://en.wikipedia.org/wiki/Constitution_of_the_People\%27s_Republic_of_China.

${ }^{63}$ See Constitution of the People's Republic of China of 4 December 1982 amended by the Fourth Amendment, of March 2004, art 33.

${ }^{64}$ See Constitution of the People's Republic of China of 4 December 1982 amended by the Fourth Amendment, of March 2004, art 10.

${ }^{65}$ China signed the International Covenant on Political and Civil Rights on 5 October 1998, and the International Covenant on Economic, Social and Cultural Rights on 27 October 1997. The latter was ratified by the Standing Committee of the National People's Assembly on 28 February 2001.

${ }^{66}$ See Constitution Of The People's Republic Of China-Wikipedia,

https://en.wikipedia.org/wiki/Constitution_of_the_People\%27s_Republic_of_China (accessed April 04, 2019). 
brought about by Constitutional Act No. 76-01 of 19 March 1976, which enshrines political pluralism through the recognition of three political parties. It began the democratization of the Senegalese political system at a time when the single party system dominated most states in sub-Saharan Africa. A few years later, a constitutional amendment will allow the recognition of a fourth political party through Act No. 78-60 of 28 December 1978. Then, in 1981, Senegalese political pluralism became effective with the constitutional law which enshrines basic multiparty system. With these various constitutional reforms, Senegalese people gain the freedom of suffrage, the freedom to compare before choosing, and this freedom that "symbolizes the idea of democracy" (Donfack, 1997). The ruling party seemed more tolerant of an opposition that was beginning to move from "contributing" to want to take over power.

In Italy, the 2001 constitutional reform introduced an innovation into the country's political life by reconfiguring competences between the State and the regions. Constitution innovation gives the province the power to legislate in cases where regulations are insufficient to enforce Community standards and international agreements. Thus, article 117 of the constitutional reform puts the legislative authority of the State and that of the region on an equal footing. It imposes the same limits on them, namely, compliance with the Constitution and Community and international commitments. That is the federalist vocation of the Italian Constitution. The principle of parity of treatment implies that there can be no limits other than those provided for in the Constitution. The law of the national parliament may not set other content limits to local legislation. ${ }^{67}$ Because, according to Article 117, legislative power is exercised by the State and the Regions in compliance with the Constitution and the constraints arising from Community legislation and international obligations. It means that the laws of the State and the Region are placed on a level of complete equality and competition. The constitutional provision of the principle of the legislative litigation establishes a close relationship between the national legislator and the regional legislator, since Parliament intervenes, through a framework law, in all matters attributed to competing for provincial legislation. The principle of competition is therefore achieved by assigning to the State the task of producing the bill of faith, ensured by the constitutional reserve, and by attaching to the regions the specific law. We see that these constitutional revisions strengthen the anchoring of democracy in several respects. Indeed, according to our indexes, they are generally considered to promote equality. However, it often happens that the power of constitutional review takes on a different philosophy.

\subsubsection{Analysis of Some Examples of Destructive Constitutional Revisions of Democracy}

These forms of constitutional amendments are regressive revisions of the democratic system. Thus, they are defined as controversial constitutional revisions whose real motivations are difficult to relate to concerns for improving the func-

${ }^{67}$ See Constitutional Review Act of 18 October 2001, art 117. 
tioning of institutions, democratic rationality and the progress of the rule of law. These categories of constitutional revisions often lead to political and institutional underdevelopment (Fall, 2011). These are controversial reforms because the majority who initiate them do not seek consensus with the rest of the political class. It proceeds unilaterally and does not take into account the strong objections of the opposition and a significant segment of public opinion. The negative constitutional revisions of democracy depending on the means used and their content vary from one country to another. For us, it will be a matter of identifying some illustrative examples. The examples of these categories of constitutional revivals are most visible in Africa. Indeed, in some African countries, the Constitutions do not escape practices that tend to slow down the democratization movements that began in the 1990s. In many cases, constitutional reforms are carried out to achieve the personal interests of their initiators. The reasons for such amendments to the Constitutions are generally to maintain a person or group of persons in power.

In Cameroon, for example, the constitutional provision relating to the mandate of the Head of State has undergone several changes in the logic of preserving power. First, it was amended in January 1996 by a constitutional amendment that increased the term of office of the President from 5 to 7 years, renewable once. Then in 2008, by Act 001 of 14 April 2008, the same provision was amended to make the presidential term unlimited. The Cameroonian constituent power replaces by this law the mention "re-electable once" by stipulating that "the Head of State is elected for a term of seven years. He may be re-elected" ${ }^{68}$ The new constitutional law restores the unlimited presidential term in Cameroon. As a result, Cameroon has only known two presidents of the Republic to date: Ahmadou Ahidjo (1960-1982) and Paul Biya (1982 to the present day). Under these conditions, the political alternative is compromised in Cameroon.

In Burkina Faso, in his quest to monopolize political power, the President of the Republic has broken the lock on limiting the presidential term to remain in place indefinitely. To achieve this objective, article 37 of the Constitution of 11 June 1991, which limited the number of presidential terms, as amended by a constitutional amendment that introduced a system of unlimited terms of office. ${ }^{69}$ Through this Constitution mechanism, President Blaise Compaoré was elected for a 7-year term, renewable indefinitely.

In Madagascar, in 1998, President Didier Ratsiraka had a referendum held on 15 March 1998 to the carry out a profound revision of the principles set out in the preamble and affecting the very structure of the country's Constitution. The version of the Constitution thus amended then allows the President of the Republic to be re-elected twice instead of once as initially provided for in the previous Constitution. ${ }^{70}$

\footnotetext{
${ }^{68}$ See Act No. 2008-1 of 14 April 2008 amending and supplementing certain provisions of Act No. 96-6 of 14 April 2008, art 6.

${ }^{69}$ See Constitutional Act of 27 January 1997, art 37.

${ }^{70}$ See Constitutional Act No. 98-01 of 8 April 1998 amending the Constitution, art 45.
} 
The Gabonese Constitution of 26 March 1991 has also been amended several times to confiscate power to satisfy the political desires of a group of men. That is how President Bongo managed to remain in office through constitutional reviews. Indeed, article 9 of the Gabonese Constitution of 26 March 1991 provided for a five-year term of office renewable once. At the initiative of President Bongo, a first reform took place on 22 April 1997, extending the President's term of office to seven years. ${ }^{71}$ Finally, this article will be revised again on 30 July 2003 to allow the President to be elected without limitation on the number of terms. ${ }^{72}$ In the same vein, the constitutional history of the Togolese Republic can be cited as an example. Article 59 of the Constitution Act stipulated that the President of the Republic is elected by direct and secret universal vote for a term of five (05) years. He can be re-elected.

Some constitutional revisions often contain the desire to settle the political accounts of their initiators. In Senegal, for example, the Constitution review lever was often lifted to resolve clan conflicts over power. President Abdoulaye Wade of the Republic in 1984 removed Habib THIAM from the presidency of the National Assembly by shortening his term of office through a revision of the Constitution. Indeed, the Constitution provided that the president of the assembly is elected for a term of five years and the constitutional change of March 1984 reduced this term to one year in the name of political equity. ${ }^{73}$ The reasons given were that legal ownership would mean that the mandate of the President and the other members of the Office of the National Assembly would be harmonized. For advocates of the constitutional revision of the Constitution, by stipulating that the President of the Assembly is elected for the duration of the legislature and the other members of the Bureau of the National Assembly elected for a year creates political discrimination. Had it not been for the desire to harm the President of the National Assembly, it was easier to grant the same mandate covering the duration of the legislature to other members of the Assembly's Bureau. The logic of settling political accounts through the constitutional amendment served to dismiss the President of the Assembly Macky SALL in political disgrace with the President of the Republic Abdoulaye WADE. Indeed, Abdoulaye Wade, President of Senegal, did not hesitate to use great means to oust Macky Sall, who was considered by the government to be a political rebel. WADE's disgrace in the President of the Assembly was actually due to the decision of the Finance Committee to hear Karim Wade, son of the President of the Republic, on the management of the public funds allocated to his structure. The matter became even more complicated with the struggle for influence at the top of the state over the disputes between Macky Sall and President Wade's son over his succession.

\footnotetext{
${ }^{71}$ See Constitutional Act No. 01/97 of 22 April 1997 amending the 1991 Constitution, art 9.

${ }^{72}$ See Act No. 13/2003 of 19 August 2003 amending Constitutional Act No. 01/97 of 22 April 1997, art 9.

${ }^{73}$ See Act No. 84-34 of 24 March 1984 abrogating and replacing the first paragraph of article 51 of the Constitution.
} 
In Togo, in 2005 the Constitution was revised to ensure that power was retained in the hands of a family and a group of politicians. Following the death of President Gnassingbé Eyadéma, Togolese deputies proceeded to amend two significant provisions of the Constitution adopted a few years ago in September 1992. ${ }^{74}$ The direct consequence of this revision is to prevent the legitimate constitutional dolphin, Mr. Fambaré Natchaba Ouattara, from acting as interim president of the deceased president. The constitutional reform carried out gave Mr. Faure Eyadéma, son of the dead President, the opportunity to become President of the Republic, thus succeeding his father. It can be seen here that no matter how many obstacles a Constitution may create on the road to constitutional change, it will not be able to prevent a government team from making the desired change. The extreme ease with which the revisions are completed in Africa testifies to the instability of these Constitutions. It is precisely this de facto instability that can partly explain the crisis in the notion of a Constitution in Africa. In this situation, it is clear that the law is more a "resource" than a "constraint," a useful political resource for the conservation of power (Sindjoun, 2009).

However, Africa is not alone in holding the revisions that are holding back the development of democracy. In other countries considered to be established democracies or major democracies, too, suffer from these evils, which undermine the rule of law and institutional progress. In the past, there have been racially motivated constitutional amendments in some southern states in the United States. In the 1890s, some states changed the voting rights granted to Blacks by the 14th and 15th amendments to the Federal Constitution following the return of Whites to power. The original legal theory of the "grandfather clause" was developed for the realization of this project of political elimination of racial minorities, especially Blacks. Thus, whites in the southern states soon joined forces to regain the political power that had escaped them on the day the blacks had obtained the right to vote. They will use the troubled period following the Civil War, the clumsiness, ignorance or greed of Blacks, to regain lost ground. The political rights of Blacks were then confiscated by white politicians with a sense of settling scores. In 1890, the various states of the South, feeling strong enough, set out to legally restrict the right of black people to vote by adopting constitutional amendments that violated naturally; if not in the letter, then at least in the spirit of amendments XIV and XV of the Federal Constitution that prohibited such practices. The southern states adopted these anti-democratic amendments in order such as Mississippi in 1890, South Carolina in 1895, Louisiana in 1898, North Carolina in 1900, Alabama in 1901. These states, through constitutional amendments, provided for clauses requiring voters to pay their taxes in full to obtain their voter cards. They also required voters to be able to understand and interpret the United States Constitution written in English. One of the most discriminatory clauses in these constitutional amendments is the grandfather clause. This clause allowed White examiners to grant the right to vote to White ${ }^{74}$ See Act No. 2002-029 of 31 December 2002 amending the Constitution of 14 October 1992. 
citizens who did not meet the conditions required for the payment of taxes at the level of study. Indeed, those who were able to prove that they were voters in 1867 or former soldiers or direct descendants of either automatically had the right to vote. That is the full discriminatory scope of these constitutional reforms because at that time Blacks were not yet emancipated and had no rights in American society. Even if these texts were later, contrary to the Constitution by the Supreme Court, they have even served as legal bases for many segregationist administrative decisions in the United States. In the face of constitutional reviews, especially those that bring a halt to the democratization process of a state, the question of judicial review of review laws may arise in constitutional law. In other words, it is appropriate here to analyse the position of the constitutional judge in the face of constitutional revisions that would violate the provisions of the Constitution.

\section{The Judge and the Control of Constitutional Review Laws}

Is it possible for the judge to review the constitutionality of laws amending the Constitution? Here, the problem of the constitutionality review of constitutional laws will be examined first in a theoretical framework, and then we will try to illustrate this theoretical framework based on the case law of the constitutional courts of different countries. In other words, we will see whether the texts of the Constitution provide for the possibility of censoring revisions of the Constitution or whether this work is the work of a judge.

\subsection{The Principle of the Absence of Constitutional Provisions Relating to the Constitutionality Control of Constitutional Revision Laws}

The constitutionality review of constitutional laws consists in verifying whether these laws conform with or contrary to the provisions of the Constitution that regulate the creation of constitutional laws and sometimes to those that determine their content. In other words, these provisions of the Constitution constitute reference standards for the review of the constitutionality of constitutional laws. In the previous developments, we have already demonstrated that a law that a constitutional revision law must respect the provisions of the Constitution that regulate its creation and in particular the constitutional provisions that impose limits on it. Thus, a constitutional revision law is irregular if it has been adopted outside the procedure provided for this purpose or if its content is contrary to the limits imposed on it. There is always the possibility of a conflict between these two categories of provisions, i.e., between a constitutional revision law and the provisions of the constitution that regulate it. If such a conflict arises, how is it resolved then? The answer to this question should be sought as to whether a constitutional law that is contrary to its limits can be invalidated in the positive law of States. In other words, the official answer to this question, to which positive law attaches legal consequences, must be sought. This solution can only found in the sources of positive law. That is why we must first look at 
constitutional legislation. A Constitution may or may not contain provisions on whether or not it is possible to review the constitutionality of constitutional laws. If a constitution contains such provisions, the question of whether or not it is possible to review the constitutionality of constitutional laws is simple: it is possible or impossible according to constitutional law.

When the Constitution itself has provided for the constitutionality review of constitutional laws, there is no difficulty in solving this problem. In this case, the Constitution will empower a body to rule on the validity of Constitution amendment laws, as well as the persons or entities to refer the matter to it. Similarly, the Constitution could determine the procedure by which this body will take its decision. In this case, if a constitutional revision law is contrary to the limits of constitutional revision, it could be challenged before the body in charge of its constitutionality review. In this case, the control of the Constitutional Review Act, following the provisions of the Constitution, shall be resolved by this body and according to the procedure determined by the Constitution. When the organization responsible for reviewing the constitutionality of constitutional laws considers that the constitutional modification law in question is unconstitutional, it may invalidate it. This invalidation decision is the final. Indeed, the interpretation of this control body will be authentic. Thus, in this case, the limits to the constitutional revision will be sanctioned by the decision of this body. However, in practice, except in a few countries, the legal regulation of the review of Constitution review laws is lacking. Indeed, apart from the Turkish Constitution $^{75}$, which expressly provides for provisions on the question of the control of constitutional requirements, almost all modern democracies exclude it or remain silent on it. In other words, the new version of Article 147 introduced by Constitutional Act No. 1488 of 20 September 1971 provided: "The Constitutional Court shall review the conformity with the Constitution of the laws and rules of procedure of the Grand National Assembly of Turkey; under the formal conditions indicated in the Constitution of the constitutional laws."

Concerning the countries that exclude the possibility of reviewing the constitutionality of constitutional review laws, we can mention the Netherlands. In this country, the Constitution expressly prohibits any form of a review of the constitutionality of laws. According to article 120 of this Constitution, "the judge shall not pass judgment on the constitutionality of laws and treaties."76 That is to say, in the Netherlands, there is no review of the constitutionality of ordinary laws and constitutional laws. Therefore, there can be no monitoring of the con-

\footnotetext{
${ }^{75}$ In Turkey, the constituent power confers jurisdiction on the constitutional court to control revisions of the Constitution. Article 147 of the 1961 Constitution as revised in 1971 and article 148 of the 1982 Constitution empower the Turkish Constitutional Court to rule on the constitutionality of constitutional laws. The Turkish Constitutional Court may therefore annul the constitutional laws if it considers that they are contrary to the formal limits of the constitutional revision. In application of this competence, the Turkish Constitutional Court has reviewed the constitutionality of constitutional laws on several occasions. It has even annulled some constitutional laws. Thus, in Turkey, the formal limits to constitutional revision are effectively sanctioned by the review by the Constitutional Court.

${ }^{76}$ See Constitution of the Netherlands of 17 February 1983, art 120.
} 
formity of constitutional laws with the limits of a Constitution review. So in such a system, constitutional laws contrary to the Constitution cannot be invalidated. Violation of the restrictions to Constitution revision is not effectively sanctioned.

In providing for constitutionality review for the other categories of laws, it often happens that the original constituent power does not expressly pronounce itself on the constitutional review laws. Where the Constitution does not contain any provision on whether the constitutionality of constitutional laws can be reviewed, the official answer to this problem could be found in constitutional jurisprudence. In other words, in the lack of a textual solution, the solution must be sought in the case of law. To know whether or not it is possible to review the constitutionality of constitutional requirements, it is necessary to look at the case law of the body responsible for considering the constitutionality of laws. If the Constitution does not contain any provision on the review of the constitutionality of constitutional requirements, the agency in charge of this matter may often declare itself incompetent. From positive law, this declaration of incompetence is necessary because it is an authentic solution. In a country whose Constitution does not contain any provision on the review of the constitutionality of constitutional laws, if the body responsible for the evaluation of constitutionality declares itself incompetent, the control of the constitutionality of constitutional laws is impossible.

In this logic, the French Constitutional Council declines its competence for the control of constitutional laws. In its decision of 6 November 1962 on the constitutionality review of constitutional revision laws, the French Constitutional Council declares that it has no competence to rule on this category of laws. The French Constitutional Court considers that the Constitution strictly delimits its jurisdiction and that it cannot, therefore, be called upon to rule on cases other than those restrictively provided for by these texts. ${ }^{77}$ The Constitutional Council of Senegal followed the same approach in its decision of 11 June 2003. Indeed, the Senegalese Constitutional Council notes that the Constitution delimits its competence and that it cannot be called upon to rule in cases other than those expressly provided for in the texts. That the Constitutional Council does not take from these texts or from any provision of the Constitution and the Organizational Law the power to rule on a constitutional revision. ${ }^{78}$

The jurisprudence policy of recognizing the uncontrollable nature of constitutional laws generally depends on the jurisdiction of constitutional judges as defined by the Constitution. The philosophical, political and legal conception of the constituent power also pushes judges responsible for reviewing the constitutionality of constitutional laws to play a spectator role in the face of violations of the Constitution. Thus, some judges or doctrinaires believe that there is no difference in nature between the original constituent power and the derived con${ }^{77}$ See French Constitutional Council, Decision No. 62-20 DC of 6 November 1962 and Decision No. 92-312 DC of September 1992 on the Maastricht Treaty.

${ }^{78}$ See Decision No. 1/C/2003/of 11 June 2003 of the Senegalese Constitutional Council. 
stituent power. There will be no difference in quality between these two powers, but a merged unity of the constituent power is manifesting itself in a political and initial (original) and legal and secondary (derived) manner. The derived constituent power is not a power of any other nature than the initial power because the constitution gives it its procedure and does not limit its scope. The constituent power being the supreme power of the State cannot be bound, even by it (Vedel, 1992). In this way, the derived constituent power can decide to repeal all the old provisions, while respecting the procedure for revising the Constitution in an entirely regular manner. This doctrinal opinion justifies and legitimizes the judge's refusal to control the revision laws which are manifestations of the Sovereign's will and which escape the appreciation of a judge, even if he is the guardian of the Constitution (Waschann, 2005). If a court declares itself incompetent to review the constitutionality of constitutional laws, its attitude can be considered as judicial self-restraint.

However, unlike the cases examined here, in some countries, constitutional judges wrestle with their jurisdiction to review the constitutionality of constitutional laws. They are doing so even if in the fact that the Constitution is silent on this question.

\subsection{The Existence of Some Case-Law Enshrining the Constitutionality Review of Constitutional Review Laws}

When the Constitution does not contain any provision on the subject of the control of the constitutionality of constitutional revision laws, the authentic solution to this question can only be found in constitutional jurisprudence. In other words, if the solution does not exist in written law, court decisions must be used. A special court can exercise this control called a Constitutional $\operatorname{court}^{79}$ or by any other judge $e^{80}$.

In certain countries, judges grant themselves the power to review the constitutionality of constitutional laws in the name of their role as guardians of the Constitution. Here, a distinction is made between the original constituent power and the derived constituent power. The ability to draft the Constitution is not of the same nature as the power of review. These are two bodies whose missions are fundamentally distinct and opposed. The consequence is that if the original constituent power is sovereign and unlikely to be subject to control, the derived constituent power must remain subordinate to the authority of the constitutional judge. Logic would, therefore, suggest that the power of review should be submitted to the constitutional court even in the absence of written texts. It is necessary to examine the case of a few countries in which judges have acquired their competence in the field of constitutional law control.

In the United States, notwithstanding the absence of express constitutional

${ }^{79}$ This is the "centralized" control system. The constitutionality of laws is reviewed by a constitutional court, i.e. by a court specially created for this purpose and located outside the ordinary judicial system.

${ }^{80}$ In the United States of America, for example, the constitutionality of laws is reviewed by the entire judicial system. This is the system of "decentralized" constitutional control. 
provisions, the Supreme Court has recognized its jurisdiction to review the regularity of Constitution review laws about the Constitution. Thus, in 1798, it ruled on the validity of a constitutional amendment in Hollingsworth v. Virginia on the exclusion of the right of citizens to bring actions in federal courts against a state. This decision on the validity of constitutional law was the first of the United States Supreme Court's decisions. It established the review of the constitutionality of constitutional laws before the analysis of the constitutionality of rules set by its 1803 decision in Marbury v. Madison. Since that date, the United States Supreme Court has issued several rulings in this regard. ${ }^{81}$ Even if these decisions did not result in the annulment of the contested constitutional laws, they demonstrate that the American judge has acquired his competence to review the constitutionality of the case.

In Africa, some constitutional courts have also established themselves to control attempts to violate the Constitution through Constitution modification. That is the case of the Constitutional Court of Mali through its decision of 12 December 2001, which invalidated a constitutional revision law on the grounds of unconstitutionality. ${ }^{82}$ It is through an interpretation of articles 88 and 118 of the Constitution that the constitutional court has given itself this competence. Otherwise, the constitutional provisions do not expressly provide for the constitutionality review of constitutional laws in Mali. In the same vein, the Constitutional Court of Benin has invalidated a constitutional law extending the mandate of deputies. Indeed, it opposed the extension of the order of the deputies to the National Assembly because the Beninese people affirm their opposition to the confiscation of power. The Court added that the determination of the Beninese people to create a state based on the rule of law and pluralist democracy requires that any revision takes into account the ideas that governed the adoption of the Constitution of 11 December $1990{ }^{83}$ In all these African States, the constitutional judge intervenes to defeat the privilege of legal immunity conferred on the laws of constitutional revision.

In Europe, when reading articles 35, 44 and 45 of the Austrian Constitution of 1 October 1920 on the power of Constitution review, it is clear that it is not materially limited. Also, article 140 of the same Constitution on the powers of the Constitutional Court to review the constitutionality of laws does not directly mention constitutional laws. This article merely states that the Constitutional Court hears the unconstitutionality of a federal or Land law. In principle, in Austria, it is impossible to review the constitutionality of the substance of constitutional rules. Because, as just explained, the control of the material constitutionality of constitutional laws presupposes that there are material limits to the Constitution review in the Constitution. Indeed, in a system where there are no material limits, the standard set by the power of constitutional review by its pro-

${ }^{81}$ See the decisions of the US Supreme Court in Myers v. Anderson de 1915; Hawke v. Smith de 1920; Dillon v. Gloss de 1921; Coleman v. Miller de 1939 etc.

${ }^{82}$ See Constitutional Court of Mali; Decision No. 01-128 of 12 December 2001.

${ }^{83}$ Decision 06-074 of 08 July 2006 of the Constitutional Court of Benin on the annulment of the constitutional law extending the mandate of deputies. 
cedure becomes a valid constitutional norm. This standard has precisely the same legal value as the original constitutional standards. For her, the question of conformity or annoyance does not arise. Therefore, in such a system, constitutional laws cannot be controlled from their formal and material regularity, because there are merely no criteria for such control. However, the term "federal law" contained in Article 140 of the Constitution has been broadly interpreted by the Austrian constitutional court. Indeed, he considers this expression to encompass all categories of laws. Thus, the judge declared his competence to review the constitutionality of legal norms. That is evidenced by its decisions of 12 December 1952 on precise control and 23 June 1988 on control of the content of constitutional requirements. In Austria, therefore, it is possible to review the constitutionality of constitutional laws despite the absence of constitutional provisions that provide for it. The derived constituent power is limited and obliged to respect the formal and substantive rules relating to the revision of the Constitution. By acting otherwise, he will be censored by the judge.

The German Constitutional Court is in line with the logic by reviewing constitutional laws, although its competence is not expressly provided for in the Constitution. Article 93 of the German Basic Law of 23 May 1949 only ensures that the Federal Constitutional Court shall rule in the event of differences of opinion or doubts as to the formal and material compatibility of federal law or the law of the land with this Basic Law. According to this article, the Constitutional judge is competent to review "federal law" or "the law of the land." The question of the control of constitutional laws is not expressly mentioned. Here again, it took an activist interpretation by the constitutional judge to find a solution. Thus, the German Constitutional Court uses the term "federal law" as integrating all forms of laws including laws for the revision of the Constitution. In this context, the German judge grants himself the competence to decide appeals for unconstitutionality against constitutional rules. In Germany, the Federal Constitutional Court considers itself competent to rule on the constitutionality of constitutional laws both in terms of their formal regularity and their content. It controls the constitutionality not only of the form but also of the content of constitutional modification. In other words, the Constitutional Court's control over Constitution reviews is not just limited to compliance with procedural rules, but also compliance with the material limitations to Constitution review. For this reason, the Federal Constitutional Court, in its decisions of 15 December 1970 and 23 April 1991, reviewed the constitutionality of two constitutional laws. It also does so in its judgments of 18 December 1953 and 23 October 1951, all of which concern constitutional laws adopted in violation of the Basic Law.

\section{Conclusion}

The lesson that can be from the Constitution review process is that they are evolving and differ at several levels from one country to another. The procedures for amending the Constitution are flexible or rigid according to the legal culture desired by each people. Thus, the Constitution without a constitutional culture is 
nothing more than a ruin of constitutionalism. Within each State, social, political and legal rules must reflect the daily realities. That is why the democratic culture is not singular. Each country should, therefore, develop its own culture of constitutional review based on a compromise between political and legal rules. The Constitution is, therefore, a sum of norms, techniques governing life in society. This state of affairs is reinforced by the emergence and generalization of the notion of the rule of law. The enforcing of democracy and the rule of law has fostered the development of new uses of the Constitution in most states around the world. As the Constitution is often at the top of the hierarchy of norms, its gaps and legal uncertainties allow each nation to adapt it to new political considerations. As a sum of proper techniques, the Constitution can easily be manipulated. For this reason, its drafters take care to set specific limits to the review process. The characteristic of the protection of the Constitution against anti-democratic practices is the place that must be given to the constitutional judge. The latter appears to be the faithful guardian of the values expressed in the Constitution, and more specifically of the rights and freedoms set out for the benefit of the citizen. The new era is, therefore, that of the citizen's entry into the constitutional space. The constitution is not only a matter for the public authorities; it is also of interest to the citizen who derives prerogatives from it. That is due to a form of disrespect of the law, the fallibility of which was broken up when the Nazi or fascist parties came to power. On this occasion, the legal norm was instrumentalized, and parliaments were allies of the executive branch in violating political rules. We have seen that universal suffrage is not enough to make a democracy. On the one hand, victorious political camps may tend to behave as tyrannical majorities and to impose their will on the political minority. On the other hand, the very reliability or fidelity of the representation of the people by elected officials can be problematic. Indeed it is true that there is a gap between elected representatives and voters, and representative democracy as it is presented today is not always satisfied. This disaffection with the law and those who vote for it has led to a kind of transfer of hope, an assignment that has benefited the judiciary.

In these circumstances, the constitutional judge becomes a regulator of democracy. Beyond political antagonists, it is a kind of constancy, a body that defends both political minorities and citizens insofar as it is the guardian of their fundamental freedoms. Clearly, in a state governed by the rule of law, the judge cannot only justify his incompetence in the face of a "deconstitutionalization ${ }^{84}$ " of the Constitution. That is why constitutional justice must be built up as a safeguard against the possible abuses of referendum democracy, especially when the people fail to be the antidote to the imperialist ambitions of the rulers.

\section{Conflicts of Interest}

The author declares no conflicts of interest regarding the publication of this paper.

${ }^{84}$ It means making the constitutional rules contrary to the Constitution itself. 


\section{References}

Ahanhanzo Glele, M. (1982). La Constitution ou loi fondamentale. Encyclopédie juridique de 1 Afrique.

Amougou, J. A. (2007). Les révisions constitutionnelles dans le nouveau constitutionnalisme africain. http://www.droitconstitutionnel.org/Atangana

Ardant, M. P. (1999). Droit et politique à la croisée des cultures.

Beaudoin, G. A., \& Thibault, P. (2004). La Constitution du Canada: institutions, partage des pouvoirs, Charte canadienne des droits et libertés. Montréal: Wilson \& Lafleur.

Bell, J. (2000). La révolution constitutionnelle au Royaume-Uni. Revue du droit public et de la science politique en France et à l'étranger, 2, 413-436.

Berriat-Saint-Prix, F. (1853). Théorie du droit constitutionnel français: Esprit des constitutions de 1848 et de 1852 et des Sénatus-consultes organiques. Paris: Videcoq Fils Ainé.

Bryce, J. B. (1900). La république américaine (Vol. 1). V. Giard et E. Brière.

Burdeau, G. (1983). Traité de science politique, t. IV: Le statut du pouvoir (3e éd.). Paris: LGDJ,

Conac, G. É. R. A. R. D. (1983). Portrait du chef d'Etat. Pouvoir, 25, 121.

Dinan, J. (2011). State constitutional developments in 2011. The Book of the States, 3-11.

Donfack, E. C. (1997). La candidature indépendante et la liberté de suffrage en droit camerounais. IDARA: Revue de IÉcole Nationale d Administration, 7, 15-50.

Esmein, A. (1906). Eléments de droit constitutionnel français et comparé. Paris: Sirey.

Fall, I. M. (2011). Les révisions constitutionnelles au Sénégal: Révisions consolidantes et révisions déconsolidantes de la démocratie sénégalaise.

Favoreu, L., \& Pfersmann O. (1992). Avant-propos. La Révision de la Constitution. Economica/PUAM.

Favoreu, L., Gaïa, P., Ghevontian, R., Mestre, J. L., Pfersmann, O., Scoffoni, G., \& Roux, A. (2016). Droit constitutionnel. Édition 2017. Paris: Dalloz.

Freund, P. A. (1967). Charles Evans Hughes as Chief Justice. Harvard Law Review, 81, 4-43. https://doi.org/10.2307/1339217

Gicquel, J. (1993). Droit constitutionnel et institutions politiques. Montchrestien.

Gicquel, J., \& Gicquel, J. É. (2009). Droit constitutionnel et institutions politiques. Montchrestien.

Gonidec, P. F. (1988). À quoi servent les Constitutions africaines? Réflexion sur le constitutionnalisme africain. Revue Juridique et Politique: Indépendance et Coopération, $42,849-866$.

Guillaume, J. (1946). Du Titre XI dans la constitution de 1946 dans ses rapports avec la théorie générale de la révision des constitutions. Doctoral Dissertation, Paris.

Gutiérrez González, J. M. (2005). United Mexican States. Constitutional Origins, Structure, and Change in Federal Countries (pp. 208-238). Montreal and Kingston McGill-Queen's UP.

Jianfu, C. (2004). La dernière révision de la Constitution chinoise. Grand bond en avant ou simple geste symbolique? Perspectives Chinoises, 2004(82).

Kelsen, H. (1928). La garantie juridictionnelle de la Constitution.

(Конституционныегарантиисудебнойпрактики).

Kelsen, H. (1962). Théorie pure du droit. Paris: Dalloz. 
Laboulaye, É. (1851). La révision de la Constitution: Lettres à un ami. Paris: A. Durand.

Laboulaye, É. (1872). Questions constitutionnelles. Paris: Charpentier.

Lavroff, D. G. (2008). De l'abus des réformes: réflexions sur le révisionnisme constitutionnel. Revue Francaise de Droit Constitutionnel, 5, 55-71.

Le Divelec, A. (2015). Dictionnaire du Droit Constitutionnel. Paris: Sirey.

Le Pillouer, A. (2009). "De la révision à l'abrogation de la constitution": Les termes du débat. Jus Politicum. Revue de Droit Politique, No. 3.

Moderne, F. (2006). Réviser la Constitution: Analyse comparative d' un concept indéterminé. Paris: Dalloz.

Pactet, P. (2003). Institutions politiques, droit constitutionnel. Paris: Armand Colin.

Pelletier, B. (1996). La modification constitutionnelle au Canada. Doctoral Dissertation, Paris: Université de Paris 1.

Rousseau, J. J. (1896). Du contrat social: Edition comprenant avec le texte définitif les versions primitives de Pouvrage collationnées sur les manuscrits autographes de Genève et de Neuchâtel. Paris: F. Alcan.

Sindjoun, L. (2009). Les grandes décisions de la justice constitutionnelle africaine: droit constitutionnel jurisprudentiel et politiques constitutionnelles au prisme des systèmes politiques africains. Bruxelles: Bruylant.

Vedel, G. (1949). Manuel élémentaire de droit constitutionnel. Paris: Recueil Sirey.

Vedel, G. (1992). Schengen et Maastricht. RFDA, No. 2, 173.

Waschann, P. (2005). La notion de justice constitutionnelle. Paris: Dalloz.

Weber, A. (2004). Notes sur la justice constitutionnelle comparée: Convergences et divergences. Annuaire International de Justice Constitutionnelle, 19, 29-41. https://doi.org/10.3406/aijc.2004.1707

Zoller, E.(1994). Splendeurs et misères du constitutionnalisme. Les enseignements de l'expérience américaine. $R D P, 1,157-184$. 